\title{
PENINGKATAN KEMAMPUAN MENULIS PUISI BEBAS DENGAN MENGGUNAKAN TEKNIK PEMETAAN PIKIRAN
}

\author{
E. Kosmajadi ${ }^{1}$ \\ Neni Rohaeni \\ e-mail: singa_wangsa@yahoo.com \\ Universitas Majalengka
}

\begin{abstract}
ABSTRAK
Penelitian dilatarbelakangi fenomena belum optimalnya hasil belajar siswa SD dalam menulis puisi bebas. Untuk mengatasinya dilakukan perbaikan pembelajaran dengan menerapkan teknik pemetaan pikiran, dengan tujuan : 1) Untuk mengetahui proses pembelajaran menulis puisi bebas di kelas V SD ;2) Untuk meningkatkan motivasi siswa kelas V SD dalam menulis puisi bebas; dan 3) Untuk meningkatkan kemampuan menulis puisi bebas bagi siswa kelas V SD melalui teknik pemetaan pikiran.

Desain penelitian menggunakan classroom action research model Kemmis dan Mc Taggart, dilaksanakan melalui tiga siklus yang terdiri atas perencanaan, tindakan, pengamatan, dan refleksi. Instrumen yang digunakan adalah pedoman observasi untuk aktifitas guru dan siswa serta lembar tes hasil belajar. Subjek penelitian siswa kelas V SD Negeri Sukamaju sebanyak 29 orang.

Penelitian berlangsung selama tiga siklus, dari hasil pengamatan pada siklus I, aktifitas siswa, aktifitas guru dalam perencanaan dan pelaksanaan pembelajaran, serta hasil tes kemampuan menulis puisi mengalami peningkatan dibandingkan dengan pra siklus, walaupun belum memuaskan. Dari hasil analisis dan refleksi pada siklus I masih terdapat kelemahan, baik aktifitas siswa dan guru maupun kemampuan siswa dalam menulis puisi, sehingga tindakan dilanjutkan kepada siklus II, demikian juga pada siklus II yang masih memerlukan siklus III. Dari analisis dan refleksi setiap siklus, diperoleh hasil bahwa aktifitas siswa, aktifitas guru dalam perencanaan dan pelaksanaan pembelajaran serta hasil tes kemampuan siswa dalam menulis puisi bebas terdapat peningkatan yang berarti, sehingga dapat disimpulkan bahwa penggunaan teknik pemetaan pikiran dapat meningkatkan kemampuan siswa kelas V SD dalam menulis puisi bebas.

Berdasarkan data-data pelaksanaan tindakan ternyata hipotesis yang dirumuskan peneliti terbukti. Maka, teknik pemetaan pikiran disarankan kepada guru untuk diterapkan pada pembelajaran menulis puisi bebas pada siswa SD.
\end{abstract}

Kata Kunci : Kemampuan menulis, menulis puisi bebas, model pembelajaran, dan teknik pemetaan pikiran.

1 Penulis adalah Dosen Tetap pada Prodi PGSD Fakultas Pendidikan Dasar dan Menengah Universitas Majalengka 


\section{Pendahuluan}

Bagi bangsa Indonesia, bahasa bukan sekedar alat komunikasi sosial, melainkan memiliki fungsi yang lebih strategis, yakni sebagai alat pemersatu bangsa. Oleh karena itu, mata pelajaran Bahasa Indonesia bagi peserta didik memegang peranan pentng, bahkan dalam konteks kesisteman, Bahasa Indonesia termasuk mata pelajaran yang harus diuji secara nasional karena kedudukannya sangat strategis. Oleh karena itu, upaya memperkenalkan, menanamkan kesadaran berbahasa, dan melatih keterampilan berbahasa bagi para peserta didik perlu dilakukan sejak dini. Dengan demikian, adanya mata pelajaran bahasa Indonesia di Sekolah Dasar sudah tepat dan patut mendapat perhatian dari semua pihak, terutama bagi guru kelas yang bertanggungjawab langsung terhadap kelancaran proses pembelajaran Bahasa Indonesia di Sekolah Dasar.

Secara teoretis, keterampilan berbahasa terdiri atas empat keterampilan utama, yakni keterampilan menyimak, berbicara, membaca, dan menulis. Keempat keterampilan tersebut berlaku bagi bahasa apa pun, termasuk bahasa Indonesia. Khusus untuk keterampilan menulis, Tarigan (2008:8), mengemukakan bahwa: "menulis atau mengarang memerlukan waktu, proses, dan latihan secara intensif', oleh karena itu harus diperkenalkan sejak dini bersamaan dengan pemberian motivasi, karena tanpa motivasi yang kuat seseorang sulit untuk mau belajar menulis.

Apabla diamati secara menyeluruh, dari empat keterampilan berbahasa tadi menulis merupakan keterampilan tersulit dan masuk kategori kemampuan paling tinggi, karena untuk dapat menulis dengan baik seseorang harus trampil menyimak, mendengarkan, dan membaca. Faktanya, orang dewasa pun sedikit sekali yang mau dan mampu menulis secara teratur, dan sedikit sekali yang memilih profesi sebagai penulis.
Oleh karena itu, bagi anak usia Sekolah Dasar, menanamkan keterampilan menulis diperlukan dukungan model pembelajaran yang tepat dengan teknik yang dapat membantu anak dalam menuangkan gagasannya ke dalam beberapa kalimat. Secara teoretis, teknik pemetaan pikiran dianggap cocok untuk mendukung hal tersebut. Peta pikiran adalah salah satu teknik pemanfaatan keseluruhan otak dengan menggunakan citra visual dan prasarana grafis lainnya untuk membentuk kesan. (Porter, 2007:153)

Peta pikiran merupakan pendekatan keseluruhan otak yang membuat peserta didik mampu membuat catatan yang menyeluruh dalam satu halaman kertas. Dengan menggunakan citra visual dan perangkat grafis lainnya, peta pikiran akan memberikan kesan yang lebih mendalam bagi anak didik (Porter, 2007 :152). Penggunaan teknik peta pikiran dalam meningkatkan kemampuan menulis pusi bebas bagi peserta didik Sekolah Dasar, atas pertimbangan bahwa teknik pemetaan pikiran (mind mapping) temuan Buzan ini dapat dilakukan dalam aktivitas apa pun dan saat belajar apa pun. Menyusun makalah, mempersiapkan materi presentasi, menyusun materi rapat, dan bahkan memetakan tema suatu karangan dapat menggunakan teknik ini. (Olivia, 2008:7).

Dalam penelitian ini, fenomena yang ditemukan di lapangan adalah rendahnya kemampuan siswa dalam menulis puisi, padahal kurikulum menuntut agar siswa memiliki kemampuan tersebut. Dalam kurikulum Bahasa Indonesia untuk siswa Kelas V semester II, dikemukakan bahwa kompetensi dasar (KD) yang harus dicapai siswa adalah "Mengungkapkan pikiran, perasaan, informasi, dan fakta secara tertulis dalam bentuk ringkasan, laporan, dan puisi bebas", dengan kompetensi dasar : 1) Meringkas isi buku yang dipilih sendiri dengan memperhatikan penggunaan ejaan; 2) Menulis laporan pengamatan atau kunjungan berdasarkan tahapan (catatan, konsep awal, 
perbaikan, final) dengan memperhatikan penggunaan ejaan; dan 3) Menulis puisi bebas dengan pilihan kata yang tepat

Dalam hal ini, guru sudah melaksanakan kewajiban sesuai dengan tugas dan fungsinya, tetapi dari hasil evaluasi diperoleh data bahwa kemampuan siswa kelas V SD Negeri Sukamaju dalam menulis puisi bebas masih rendah. Hasil observasi awal diketahi bahwa dari 28 orang siswa hanya 6 orang $(21,43 \%)$ yang memiliki nilai di atas KKM, 14 orang $(50,00 \%)$ yang memiliki nilai sama dengan KKM, dan sisanya 8 orang $(28,57 \%)$, memiliki nilai di bawah KKM.

Hal ini diduga kurang tepatnya penggunaan metode dan teknik pembelajaran yang dipilih oleh guru, sehingga siswa merasa kesulitan untuk menuangkan ide atau gagasannya ke dalam bentuk tulisan, khususnya dalam menulis puisi bebas. Dari hasil kajian teori, ditemukan penjelasan bahwa guru memiliki kewajiban untuk memikirkan strategi apa yang akan digunakan agar tujuan pembelajaran tercapai, sebagaimana dike-mukakan Senjaya (2008:11) bahwa "Strategi pembelajaran adalah suatu kegiatan pembelajaran yang harus dikerjakan guru dan siswa agar tujuan pembelajaran dapat dicapai secara efektif dan efisien“. Selanjutnya, dengan mengutip pemikiran David, Senjaya (2008: 14) mengemukakan bahwa dalam strategi pembelajaran terkandung makna perencanaan. Artinya, strategi masih bersifat konseptual tentang keputusan-keputusan yang akan diambil dalam suatu pelaksanaan pembelajaran.

Dengan demikian, peneliti berasumsi bahwa dengan menggunakan teknik pemetaan pikiran, kemampuan menulis puisi bebas bagi siswa akan meningkat. Teknik ini cocok diterapkan di siswa SD kelas V karena "pada usia ini siswa mampu mengembangkan daya nalarnya dengan melatih anak untuk mengungkapkan pendapat, gagasan atau penilaiannya terhadap berbagai hal." (Yusuf,2008:179).
Keberhasilan siswa dalam menulis puisi bebas dapat dilihat dari hasil pembelajaran pada proses dan hasil menulis puisi bebas. Maka apabila prosesnya baik, diharapkan hasilnya pun akan baik. Oleh karena itu, peneliti sangat tertarik untuk melakukan penelitian tindakan kelas yang bertujuan untuk meningkatkan kemampuan menulis puisi pada siswa Sekolah Dasar dengan menggunakan teknik pemetaan pikiran. Teknik pemetaan pikiran dapat digunakan karena sesuai dengan usia sekolah dasar untuk melatih daya nalar secara sistematis.

Berdasarkan latar belakang yang telah diuraikan di atas, peneliti tertarik meneliti tentang kemampuan siswa dalam menulis puisi bebas yang bertujuan : 1) Untuk mengetahui proses pembelajaran menulis puisi bebas dengan menggunakan teknik pemetaan pikiran; 2) Untuk meningkatkan motivasi siswa dalam menulis puisi dengan menggunakan teknik pemetaan pikiran; dan 3) Untuk meningkatkan kemampuan menulis puisi bebas bagi siswa melalui teknik pemetaan pikiran.

Kemampuan adalah sebagai suatu kapasitas individu untuk mengerjakan berbagai tugas dalam suatu pekerjaan. Seluruh kemampuan seorang individu pada hakekatnya tersusun dari dua perangkat faktor yaitu kemampuan intelektual dan kemampuan fisik. Kemampuan intelektual adalah kemampuan yang diperlukan untuk menjalankan kegiatan mental. Sedangkan kemampuan fisik adalah kemampuan yang diperlukan untuk melaksanakan tugas-tugas yang menuntut stamina, kecekatan, kekuatan dan keterampilan serupa (Robbins, 2006). Menurut Depdiknas (2007:107) "Kemampuan dapat dikatakan sebagai kesanggupan, kekuatan, dan kenyataan”.

Di samping itu, perlu juga penulis sampaikan bahwa menulis merupakan keterampilan berbahasa. Menurut Heru Kurniawan (2009:151) "Berdasarkan pada jenis keterampilan berbahasa yang dimiliki manusia, menulis merupakan jenis 
keterampilan berbahasa yang menduduki posisi paling tinggi setelah membaca, berbicara, dan menyimak". Pendapat lain dikemukakan Tarigan dalam Kurniawan (2009:151), yang menjelaskan bahwa "Aktif ini terjadi karena menulis bersifat menyampaikan bentuk gagasan dalam bentuk kode tulisan, yang tentunya, menulis bisa dilakukan setelah seseorang bisa "menulis" dan "membaca", oleh karena itu berdasarkan pada kemampuan kognitif siswa, keterampilan berbahasa secara urut yang akan dilalui manusia adalah: menyimak, berbicara, membaca, dan menulis". Secara filosofis, menulis secara kodrati menjadi keterampilan berbahasa yang paling tinggi.

Dalam penelitian ini, yang dimaksud adalah kemampuan menulis. Menurut Tarigan dalam Sumarno (2009:5) "Menulis berarti mengekpresikan secara tertulis gagasan, ide, pendapat, atau pikiran dan perasaan". Kemampuan menulis, baik bagi siswa maupun orang dewasa memiliki tujuan tertentu. Secara teoretis, Hugo dalam Tarigan (2004:24) mengklasifikasikan tujuan menulis, antara lain: 1) Tujuan penugasan (assingnment purpose); 2) Tujuan altruistik (altruistic purpose), tujuan persuasi (persuasive purpose); 3) Tujuan Persuasif (Persuassive Purpose ) ; 4) Tujuan penerangan (informational purpose), tujuan penyataan (self- expressive purpose) ; 5) Tujuan Pernyataan diri (Self expressive purpose) ; 6) Tujuan kreatif (creative purpose) ; 7) Tujuan pemecahan masalah (problem-solving purpose). Hasani (2005:2), menyatakan "Menulis merupakan keterampilan berbahasa yang dipergunakan untuk berkomunikasi secara langsung". Tentu saja, dalam menulis memerlukan proses yang cukup panjang.

Yunus (2009) mengemukakan bahwa "Proses menulis terdiri dari tiga tahap, antara lain: tahap prapenulisan, penulisan, dan pascapenulisan". Yunus menjelaskan lebih lanjut, tahap prapenulisan terdiri dari memilih topik, tujuan, dan sasaran karangan, mengumpulkan bahan, serta menyusun kerangka karangan. Hal ini dilakukan sebagai tahap persiapan untuk menulis. Kemudian dilanjutkan dengan penjabaran dan pengembangan dari tiap-tiap kerangka yang telah disusun dengan memperhatian kelogisan dan keruntutan kalimat. Kegiatan ini disebut tahap penulisan. Hasil pengembangan pada tahap penulisan direvisi dan diperbaiki agar menjadi suatu karangan yang baik di tahap pasca penulisan.

Dari penjelasan di atas, maka dapat disimpulkan bahwa pengertian menulis adalah kegiatan menuangkan ide, gagasan, dan pengalaman dalam bentuk bahasa tulis untuk menyampaikan pesan kepada pembacanya. Dalam keterampilan berbahasa, menulis merupakan keterampil-an yang paling rumit dan kompleks, sehingga tidak semua orang memiliki keterampilan tersebut.

Dilihat dari jenisnya, tulisan terdiri atas dua jenis, yaitu fiksi dan nonfiksi. Karangan fiksi adalah karangan yang sifatnya rekaan, karangan, khayalan (Kokonata, 2009). Karangan cerita fiksi merupakan hasil olahan imajinasi seorang pengarang berdasarkan pandangan, tafsiran, dan penilaiannya terhadap peristiwa-peristiwa yang pernah terjadi secara nyata ataupun yang hanya terjadi dalam khayalan penulis saja. Nonfiksi adalah bentuk tulisan yang menjelaskan atau menggambarkan sesuatu yang nyata dan terjadi. Penulisan nonfiksi harus memaparkan bukti-bukti yang ada sesuai dengan topik bahasan. Tujuan dibuatnya tulisan nonfiksi adalah untuk memberikan informasi yang jelas dan tepat kepada pembaca, sehingga pembaca memperoleh pengetahuan dan dapat digunakan dalam kehidupan sehari-hari. Contoh dari nonfiksi antara lain, artikel, paper, laporan, dan sebagainya. (Marwoto, 2009)

Berdasarkan penjelasan tersebut, maka dapat diketahui bahwa puisi adalah salah satu jenis karangan fiksi, karena merupakan karangan seseorang melalui hasil olahan yang bersifat imajinatif atau khayalan. Kemampuan itulah yang harus dimiliki siswa SD. 
Tentang menulis puisi, Jabrohim dkk.(2009:67), menulis puisi merupakan suatu kegiatan seorang "intelektual", yakni kegiatan yang menuntut seseorang harus benar-benar cerdas, menguasai bahasa, luas wawasannya, dan peka perasaannya." Menurut Sayuti (2002:24) puisi adalah karya estetis yang memanfaatkan sarana bahasa secara khas. Menurut Suryaman (2005:20) puisi merupakan karya emosi, imajinasi, pemikiran, ide, nada, irama, kesan panca indera, susunan kata, kata-kata kiasan, kepadatan, dan perasaan yang bercampur baur dengan memperhatikan pembaca. Senada dengan Suryaman, Waluyo (2005:1) menyatakan bahwa puisi adalah karya sastra yang dipadatkan, dipersingkat, dan diberi irama dengan bunyi yang padu dan pemilihan kata-kata kiasan (imajinatif).

Kosasih, E (2008:30) mengemukakan bahwa "Puisi adalah bentuk karya sastra yang tersaji secara monolog, menggunakan kata-kata indah dan kaya akan makna". Menurut Triningsih (2008:1) Puisi adalah karya sastra yang dipadatkan, dipersingkat, dan diberi irama dengan bunyi yang padu dan pemilihan kata-kata kias". Dengan demikian, menurut penjelasan dari beberapa ahli di atas, dapat disimpulkan bahwa puisi adalah hasil karya berupa tulisan-tulisan yang indah dan mempunyai makna.

Menurut Triningsih (2008:3) unsur pembentuk puisi meliputi :

1) Hakikat Puisi, yaitu curahan hati yang diungkapkan penyair (penulis puisi) dalam puisi, disebut juga isi puisi yang terdiri atas tema, rasa, nada, dan amanat.

2) Struktur Bentuk Puisi, disebut juga unsur pembangun puisi secara fisik yang terdiri atas larik, bait, pertautan, diksi, imajinasi, rima dan irama.

Secara garis besar, dalam proses pembelajaran di SD, materi yang dipelajari dalam puisi meliputi kegiatan : 1) Menentukan gagasan pokok berdasarkan pengalaman; 2) Menulis puisi berdasarkan gagasan pokok; 3) Menentukan makna yang terkandung dalam sebuah puisi; dan 4) Menentukan amanat dalam sebuah puisi,

Untuk meningkatkan kemampuan siswa dalam menulis puisi, salah satu teknik pembelajaran yang dapat digunakan adalah pemetaan pikiran. Teknik tersebut dapat menarik minat dan gairah siswa, karena siswa akan lebih banyak berpikir sendiri untuk mengembangkan kreatifitasnya dalam memecahkan masalah. Menurut Tony Buzan (2009:6), indikator pemetaan pikoran (Mind Mapping) adalah: a) merencanakan, b) berkomunikasi, c) menjadi lebih kreatif, d) menyelesaikan masalah, e) memusatkan perhatian, f) menyusun dan menjelaskan pikiran-pikiran, g) mengingat dengan lebih baik ; h) belajar lebih cepat dan efisien, dan i) melatih "gambar keseluruhan".

Dengan menggunakan teknik pemetaan pikiran kemampuan siswa dalam menulis puisi bebas akan meningkat, sistematis dan dapat diikuti oleh siswa SD.

\section{Desain penelitian}

Metode yang digunakan adalah penelitian tindakan kelas (Classroom Action Research). Alasan teoretis penggunaan metode tersebut antara lain mengacu pada pendapat Hopkins dalam Muslich (2009), bahwa PTK merupakan "suatu bentuk kajian yang bersifat reflektif, yang dilakukan oleh pelaku tindakan untuk meningkatkan kemantapan rasional dari tindakantindakannya dalam melaksanakan tugas dan memperdalam pemahaman terhadap kondisi dalam praktik pembelajaran." Dalam proses pembelajaran, guru sering menemukan permasalahan, baik menyangkut peserta didik maupun kelemahan guru yang harus segera dicari solusinya. Maka, sebagai solusi untuk memecahkan masalah tersebut, pendidik dituntut untuk melakukan penelitian tindakan kelas sesuai dengan karakteristik penelitian tindakan kelas seperti yang dikemukakan Wardhani (2007:15), yaitu :

1. Adanya permasalahan dalam PTK yang dipicu oleh munculnya kesadaran pada diri pendidik bahwa praktek yang 
dilakukannya selama ini di dalam kelas mempunyai masalah yang perlu diselesaikan.

2. Self-reflektif inquiri, atau penelitian melalui refleksi diri merupakan ciri PTK yang paling esensial.

3. Penelitian tindakan kelas dilakukan di dalam kelas, sehingga fokus penelitian ini adalah kegiatan pembelajaran berupa perilaku pendidik dan siswa dalam melakukan interaksi.

4. Penelitian tindakan kelas bertujuan memperbaiki pembelajaran.

Model yang digunakan adalah model spiral Kemmis dan Mc.Taggart dalam Aqib (2006:22) sebagai berikut :

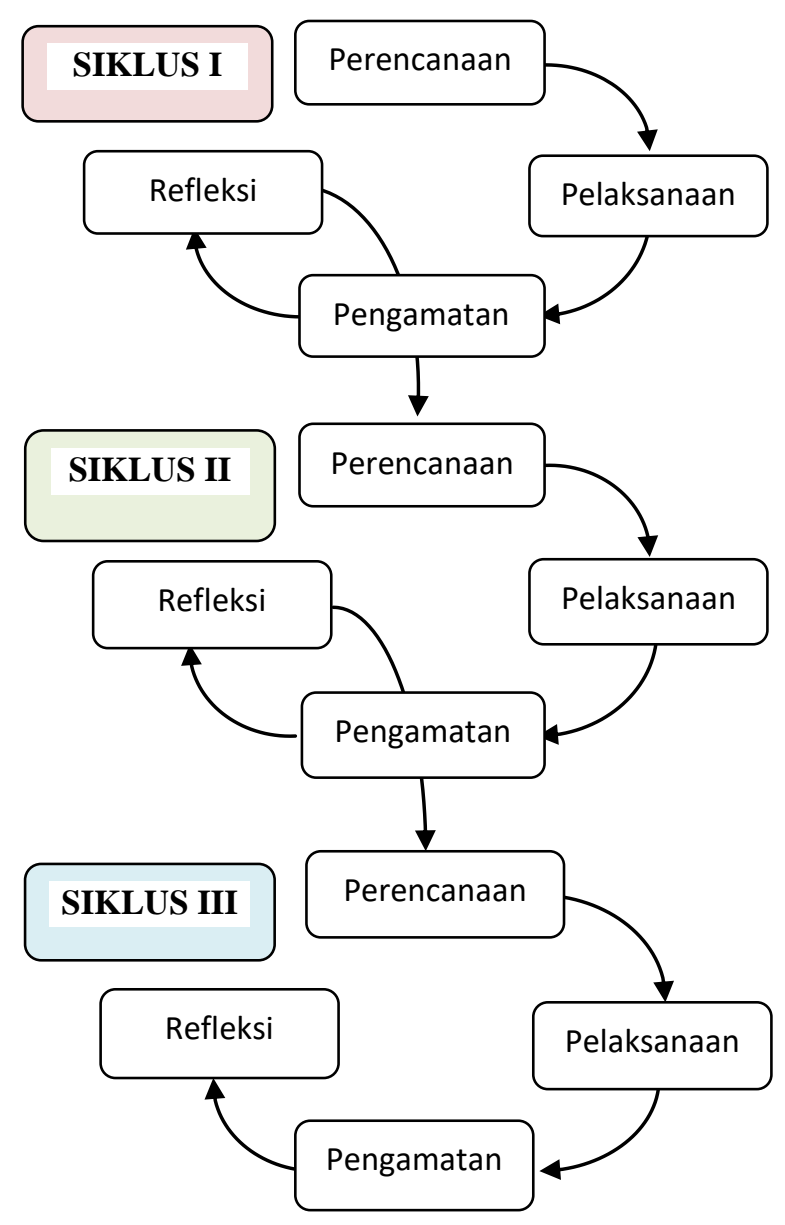

Gambar 1.

Siklus Penelitian Tindakan Kelas

Berdasarkan model di atas, penilitian ini dilakukan secara bertahap, mulai dari studi pendahuluan, perencanaan tindakan, pelaksanaan tindakan, analisis, dan refleksi. Lokasi penelitian di Sekolah Dasar dengan subjek sebanyak 27 siswa kelas V.

Teknik pengumpulan data menggunakan teknik observasi untuk aktifitas guru dan siswa serta teknik tes untuk mengukur hasil belajar siswa dalam menulis puisi bebas. Data yang diperoleh dianalis sesuai sifat data.

Untuk data hasil observasi, skor ideal dijumlahkan kemudian diinterpretasikan kepada lima kategori, yaitu Baik Sekali (BS), Baik (B), Cukup (C), Kurang (K), dan Kurang Sekali (KS). Sedangkan data hasil tes, yang diukur melalui empat aspek, yaitu pengembangan ide/gagasan, penggunaan majas personifikasi, penggunaan majas simile, dan rima, jumlah skor setiap aspek dibagi skor ideal kemudian dibandingkan dengan nilai KKM yang telah ditetapkan, yaitu 66.

\section{Hasil dan Pembahasan}

Sebelum dilakukan tindakan, peneliti terlebih dahulu melakukan pengamatan terhadap kondisi hasil belajar siswa dalam menulis puisi bebas. Hasilnya menunjukkan bahwa kemampuan siswa masih rendah, dibuktikan dengan hasil pembelajaran bahwa hanya lima orang siswa yang memperoleh nilai di atas KKM, selebihnya berada di bawah nilai KKM $(<66)$. Setelah dianalisis, dari 27 siswa hanya 18,52\% yang masuk kategori tuntas. Hal ini mengandung arti bahwa proses pembelajaran menulis puisi bebas belum memenuhi standar yang ditetapkan, sehingga diperlukan tindakan nyata untuk memperbaikinya.

Selanjutnya dilakukan tindakan siklus I dengan menempuh tahapan-tahapan sesuai dengan prosedur, mulai dari pembuatan RPP, pelaksanaan tindakan, analisis, dan refleksi. Kompetensi Dasar yang akan diberikan kepada peserta didik adalah : "Menulis puisi bebas dengan pilihan kata yang tepat", dengan tujuan agar : 1) Siswa dapat menulis puisi berdasarkan gagasan pokok dengan 
tema yang tepat; dan 2) Siswa dapat memilih kata/diksi dengan tepat dan menarik. Pada kegiatan pembelajaran inti, setiap kelompok diberi kebebasan untuk menentukan gagasan pokok/topik berdasarkan subyek yang diamati di luar sekolah dan pemetaan pikiran yang dikembangkan. Proses pembelajaran diakhiri dengan tes, sementara selama proses pembelajaran berlangsung dilakukan pengamatan terhadap aktifitas siswa dibantu oleh seorang observer.

Dari analisis dan pengolahan data diperoleh hasil bahwa aktifitas siswa, diperoleh rata-rata sebesar 5,56, selanjutnya dibandingkan dengan tabel interpretasi sebagai berikut :

Tabel : 1

Tabel Interpretasi Hasil Pengamatan Aktifitas Siswa

\begin{tabular}{|c|c|c|}
\hline No & Rentang Skor & Kategori \\
\hline 1 & $7-9$ & Baik \\
\hline 2 & $4-6$ & Cukup \\
\hline 3 & $1-3$ & Kurang \\
\hline
\end{tabular}

Dengan demikian diketahui bahwa aktifitas siswa dalam proses pembelajaran menulis puisi bebas dengan pilihan kata yang tepat pada tindakan siklus I berada pada kategori cukup, karena nilai 5,56 berada pada interval nilai antara 4-6 yang termasuk kategori Cukup.

Aktifitas guru terdiri atas dua pengamatan, yakni pengamatan terhadap perencanaan (RPP) dan pelaksanaan pembelajaran. Aspek yang diamati dalam proses ini menyangkut indiktor-indikator penulisan RPP yang baik dan langkahlangkah pembelajaran yang sesuai dengan standar mutu.

Hasil pengamatan yang dilakukan oleh observer diolah dan dianalisis secara kualitatif sesuai sifat dengan sifat data. Hasilnya diperoleh jumlah persentase untuk aktifitas guru dalam mebuat perencanaan sebesar 78\%, kemudian nilai tersebut dibandingkan dengan tabel interpretasi data sebagai berikut.
Tabel : 2

Tabel Interpretasi Hasil Pengamatan Aktifitas Guru pada Tahap Perencanaan Siklus I

\begin{tabular}{|c|c|c|}
\hline No & Rentang Persentase & Kategori \\
\hline 1 & $81 \%-100 \%$ & Baik Sekali \\
\hline 2 & $61 \%-80 \%$ & Baik \\
\hline 3 & $41 \%-60 \%$ & Cukup \\
\hline 4 & $21 \%-40 \%$ & Kurang \\
\hline 5 & $0 \%-20 \%$ & Kurang Sekali \\
\hline
\end{tabular}

Setelah dibandingkan, diketahui bahwa aktifitas guru pada tahap perencanaan pembelajaran (RPP) pada tindakan siklus I sudah baik, karena tingkat persentase $78 \%$ berada pada interval antara $61 \%-80 \%$ yang termasuk kategori baik. Sedangkan aktifitas guru pada tahap pelaksanaan, dari hasil pengamatan yang dilakukan observer diperoleh persentase sebesar 72,86\%. Melalui pola yang sama, nilai persentase tersebut dibandingkan dengan tabel interpretasi, hasilnya masuk kategori baik, karena berada pada interval antara $61 \%$ $80 \%$.

Adapun untuk mengetahui data tentang hasil tes kemampuan siswa dalam menulis puisi bebas, diperoleh dari hasil tes terhadap empat aspek yang dipelajari, yaitu ide/gagasan, majas personifikasi, majas simile, dan rima. Setelah diolah dan dianalisis, diketahui bahwa dari 27 siswa yang mengikuti pembelajaran tentang menulis puisi bebas dengan pilihan kata yang tepat, hanya 7 orang siswa atau $25,92 \%$ yang masuk kategori tuntas, sisanya sebanyak 20 orang siswa atau $74,08 \%$ belum tuntas. Untuk mengetahui tingkat ketuntasan bagi masing-masing siswa, nilai yang diperolehnya dibandingkan dengan dengan Kriteria Ketuntasan Minimal (KKM) yang telah ditetapkan sebelumnya, yaitu 66 .

Dari hasil analisis dan refleksi terhadap tindakan pad siklus I, diketahui bahwa tindakan siklus I memperlihatkan kemajuan yang berarti. Artinya penerapan teknik pemetaan pikiran dapat meningkatkan kemampuan siswa dalam menulis puisi bebas, tetapi belum memuaskan, sehingga 
perlu dilanjutkan dengan siklus berikutnya. Secara spesifik dapat disimpulkan bahwa pada proses pembelajaran siklus I terdapat peningkatan baik dilihat dari aktifitas guru dan siswa, maupun dilihat dari nilai rata-rata kelas dan tingkat persentase ketuntasan belajar. Hal ini terbukti dengan adanya peningkatan pada nilai rata-rata yang sebelumnya 57,59 menjadi 58,48 dan adanya peningkatan kemampuan siswa dalam menulis puisi bebas dengan mendapat nilai di atas KKM. Sebelumnya hanya 5 orang siswa, meningkat menjadi 7 orang siswa, atau dari $18,52 \%$ menjadi $25,92 \%$.

Tindakan selanjutnya dilakukan dengan pola dan langkah yang sama, hanya terdapat perbedaan dalam tindakan inti pada saat proses pembelajaran, berupa tindakan perbaikan atas dasar hasil refleksi setiap akhir siklus. Dengan kata lain, kelemahan yang ditemukan pada siklus I diperbaiki pada siklus II, kelemahan pada siklus II diperbaiki pada siklus III, dan akhirnya kemampuan siswa dalam menulis puisi bebas semakin baik.

Pada siklus II, aktifitas siswa secara keseluruhan diperoleh nilai 6,18, masuk kategori Cukup. Aktifitas guru dalam perencanaan diperoleh persentase sebesar $88 \%$, masuk kategori Baik Sekali. Aktifitas guru dalam pelaksanaan pembelajaran diperoleh persentase sebesar $82,86 \%$, masuk kategori Baik Sekali.

Hasil tes kemampuan siswa dari sejumlah subyek, terdapar 15 orang siswa atau 55,55 \% yang masuk kategori tuntas, sisanya sebanyak 12 orang siswa atau $44,45 \%$ belum tuntas, namun demikian tampak dengan jelas adanya peningkatan.

Hasil analisis dan refleksi, pada proses pembelajaran siklus II terdapat peningkatan yang cukup berarti, baik dilihat dari nilai rata-rata kelas maupun tingkat persentase ketuntasan yang cukup memuaskan. Hal ini terbukti dengan adanya peningkatan pada nilai rata-rata yang sebelumnya 58,48 menjadi 66,04 dan adanya peningkatan kemampuan siswa dalam menulis puisi bebas dengan jumlah siswa yang mendapat nilai di atas KKM yang sebelumnya 7 orang siswa menjadi 15 orang siswa, atau dari $25,92 \%$ menjadi $55,55 \%$.

Pada tindakan terakhir (Siklus III), aktivitas siswa secara keseluruhan diperoleh nilai 7,07, masuk kategori Baik. Aktifitas guru dalam perencanaan diperoleh persentase sebesar 94\%, masuk kategori Baik Sekali. Aktifitas guru dalam pelaksanaan pembelajaran diperoleh persentase sebesar 94,28\%, masuk kategori Baik Sekali.

Kemudian, hasil tes kemampuan siswa tentang kemampuan menulis puisi bebas dari sejumlah subyek, seluruh siswa sebanyak 27 orang telah mencapai ketuntasan belajar (100\%), tidak seorang pun siswa yang belum tuntas $(0 \%)$. Hasil analisis dan refleksi siklus III menunjukkan bahwa pada proses pembelajaran siklus III terdapat peningkatan baik dilihat dari nilai rata-rata kelas maupun tingkat persentase ketuntasan yang sangat memuaskan.

Hal ini terbukti dengan adanya peningkatan pada nilai rata-rata yang sebelumnya 66,04 menjadi 76,11 dan adanya peningkatan kemampuan siswa dalam menulis puisi bebas dengan jumlah siswa yang mendapat nilai di atas KKM yang sebelumnya 15 siswa menjadi 27 siswa, atau dari $55,55 \%$ menjadi $100 \%$. Penelitian ini diakhiri sampai siklus III dan penggunaan teknik pemetaan pikiran (mind mapping) diyakini tepat untuk meningkatkan kemampuan siswa dalam menulis puisi bebas dengan pilihan kata yang tepat.

Penelitian tindakan siklus III yang merupakan akhir dari penelitian tindakan kelas ini membuktikan bahwa penggunaan teknik pemetaan pikiran (mind mapping) dalam pembelajaran Bahasa Indonesia khususnya materi menulis puisi bebas dengan 
pilihan kata yang tepat, dapat meningkatkan kemampuan menulis puisi bebas bagi siswa Kelas V SD. Artinya, hasil penelitian dapat menjawab rumusan masalah yang kedua, bahwa teknik pemetaan pikiran dapat meningkatkan kemampuan menulis puisi bagi siswa kelas V SD, sehingga teknik pemetaan pikiran (mind mapping) dapat dijadikan salah satu alternatif bagi guru dalam pembelajaran Bahasa Indonesia.

Secara lebih rinci perkembangan aktifitas dan kemampuan siswa Kelas V SD dalam menulis puisi bebas dengan pilihan kata yang tepat, mulai dari siklus I sampai dengan siklus III, peneliti sajikan pada tabel berikut ini :

Tabel : 3

Rekap Peningkatan Aktifitas Siswa dalam Proses Pembelajaran Menulis Puisi Bebas dengan Pilihan Kata yang Tepat

\begin{tabular}{|c|l|c|c|c|c|c|}
\hline \multirow{2}{*}{ No } & \multirow{2}{*}{$\begin{array}{c}\text { Aspek yg } \\
\text { Diamati }\end{array}$} & \multicolumn{2}{|c|}{ Tindakan Siklus } & \multicolumn{2}{c|}{ Peningkatan (\%) } \\
\cline { 3 - 7 } & I & II & III & I ke II & II ke III \\
\hline 1 & Keaktifan & 1,89 & 2,29 & 2,44 & $21,16 \%$ & $6,55 \%$ \\
\hline 2 & Kerjasama & 2,11 & 2,18 & 2,59 & $3,31 \%$ & $18,81 \%$ \\
\hline 3 & Ketelitian & 1,56 & 1,70 & 2,04 & $8,97 \%$ & $20,00 \%$ \\
\hline
\end{tabular}

Dari data yang tertera pada Tabel 3 di atas, setelah dianalisa diketahui bahwa aspek keaktifan mengalami peningkatan dari siklus I ke siklus II sebesar 21,16 \%, hal ini erat kaitannya dengan aspek kerjasama, artinya karena pada siklus I keaktifan rendah maka peningkatan aspek kerjasama pada siklus II hanya 3,31\%. Pada saat aspek keaktifan meningkat $21,16 \%$ pada siklus II, berkaitan erat dengan peningkatan kerjasama dari siklus II ke siklus III sehingga mencapai $18,81 \%$. Aspek kerja sama pun berkaitan erat dengan aspek ketelitian, terbukti bahwa pada saat kerjasama meningkat, dari siklus II ke siklus III aspek ketelitian meningkat $20,00 \%$.

Dengan demikian dapat dipahami bahwa semua aspek yang diteliti satu sama lain memiliki keterkaitan, sehingga pengamatan terhadap aktifitas siswa menjadi penting.
Tabel : 4

Rekap Peningkatan Kemampuan Siswa dalam Menulis Puisi Bebas dengan Pilihan Kata yang Tepat

\begin{tabular}{|c|l|c|c|c|c|c|}
\hline \multirow{2}{*}{ No } & \multirow{2}{*}{$\begin{array}{c}\text { Aspek yg } \\
\text { Diamati }\end{array}$} & \multicolumn{2}{|c|}{ Tindakan Siklus } & \multicolumn{2}{c|}{ Peningkatan (\%) } \\
\cline { 3 - 7 } & I & II & III & I ke II & II ke III \\
\hline 1 & Gagasan & 2,15 & 2,37 & 2,48 & $10,23 \%$ & $4,64 \%$ \\
\hline 2 & $\begin{array}{l}\text { Majas } \\
\text { Personifikasi }\end{array}$ & 1,59 & 2,07 & 2,26 & $30,19 \%$ & $9,18 \%$ \\
\hline 3 & Majas Simile & 1,70 & 1,89 & 2,23 & $11,17 \%$ & $17,98 \%$ \\
\hline 4 & Rima & 1,59 & 1,63 & 2,15 & $2,15 \%$ & $24,18 \%$ \\
\hline
\end{tabular}

Dari data yang tertera pada Tabel 4 di atas, diketahui bahwa perkembangan aspek ide/gagasan, majas personifikasi, majas simile, dan rima pada setiap siklus mengalami peningkatan. Hal ini mengandung arti bahwa penggunaan teknik pemetaan pikiran (mind mapping) dalam proses pembelajaran menulis puisi bebas dengan pilihan kata yang tepat dapat meningkatkan kemampuan siswa. Untuk menggambarkan perkembangan peningkatan tersebut, dapat dilihat juga dari tingkat ketuntasan dengan cara membandingkan nilai yang diperoleh siswa dengan KKM (66). Selengkapnya, peneliti sajikan dalam tabel berikut ini.

Tabel : 5

Rekap Peningkatan Nilai Rata-rata Kelas dan Ketuntasan Hasil Belajar Menulis Puisi Bebas dengan Pilihan Kata yang Tepat

\begin{tabular}{|c|l|c|c|r|r|r|}
\hline \multirow{2}{*}{ No } & \multicolumn{2}{|c|}{$\begin{array}{r}\text { Aspek yg } \\
\text { diamati }\end{array}$} & \multicolumn{3}{|c|}{$\begin{array}{c}\text { Tindakan } \\
\text { Siklus }\end{array}$} & \multicolumn{2}{c|}{$\begin{array}{r}\text { Peningkatan } \\
(\%)\end{array}$} \\
\cline { 3 - 7 } & I & II & III & I ke II & II ke III \\
\hline 1 & $\begin{array}{l}\text { Nilai rata-rata } \\
\text { kelas }\end{array}$ & 58,48 & 66,04 & 76,11 & $12,93 \%$ & $15,25 \%$ \\
\hline 2 & $\begin{array}{l}\text { Persentase } \\
\text { Keberhasilan }\end{array}$ & $25,92 \%$ & $55,55 \%$ & $100 \%$ & $14,30, \%$ & $80,00 \%$ \\
\hline
\end{tabular}

Dari data yang tertera pada Tabel 5 di atas, diketahui bahwa perkembangan nilai rata-rata kelas dan persentase kriteria ketuntasan minimal mengalami peningkatan. Nilai rata-rata kelas dari siklus I ke siklus II mengalami peningkatan sebesar $12,93 \%$, sedangkan dari siklus II ke siklus III naik 15, 25\%. Perkembangan kemampuan siswa dapat dilihat juga dari persentase ketuntasan hasil belajar, bahwa dari siklus I ke siklus II mengalami peningkatan sebesar $114,30 \%$, dan dari 
siklus II ke siklus III mengalami peningkatan sebesar $80 \%$.

Dari data-data tersebut diketahui bahwa pembelajaran Bahasa Indonesia khusus materi menulis puisi bebas dengan pilihan kata yang tepat dengan menggunakan teknik pemetaan pikiran (mind mapping) terbukti dapat meningkatkan kemampuan siswa dalam menulis puisi bebas, karena secara umum nilai rata-rata kelas maupun persentase siswa yang mendapat nilai $\geq 66$ sudah tercapai. Artinya, penggunaan teknik pemetaan pikiran (mind mapping) dalam pembelajaran Bahasa Indonesia dapat meningkatkan kemampuan menulis puisi bagi siswa kelas V SD

\section{Simpulan dan Saran}

Berdasarkan hasil pengolahan dan analisis data penelitian tindakan kelas, tentang peningkatan kemampuan siswa SD dalam menulis puisi bebas melalui penerapan pemetaan pikiran diperoleh simpulan bahwa proses pembelajaran menulis puisi di kelas $\mathrm{V}$ SD dengan menggunakan teknik pemetaan pikiran sudah efektif, dan teknik pemetaan pikiran dapat meningkatkan kemampuan menulis puisi bagi siswa kelas V SD. Secara keseluruhan, baik aktifitas siswa selama proses pembelajaran maupun hasil tes kemampuan menulis menunjukkan peningkatan pada setiap siklusnya.

Berdasarkan kesimpulan, kepada guru kelas, khususnya dalam proses pembelajaran bahasa Indonesia disarankan agar teknik pemetaan pikiran dijadikan sebagai salah satu alternatif teknik pembelajaran, karena hasil penelitian membuktikan bahwa teknik pemetaan pikiran dapat meningkatkan kemampuan siswa SD dalam menulis puisi bebas. Selain itu, disarankan juga agar dicoba untuk materi yang lain.

Bagi peneliti lain, disarankan untuk meneliti teknik pembelajaran lainnya yang memungkinkan dapat meningkatkan kemampuan siswa dalam menulis puisi.

\section{DAFTAR PUSTAKA}

Abidin, Y. (2009). Kemampuan Menulis dan Berbicara Akademik. Bandung: Rizki Press.

Aqib, dkk. (2006). Penelitian Tindakan Kelas. Bandung: Irama Widya.

Basuki.T. (2000) Pembelajaran Mate-matika Disertai Penyusunan Peta Konsep, Bandung : PPs UPI Bandung.

Bobbi, De Porter. Dkk. (2000) Quantum Teaching; Mempraktekan Quantum Learning di Ruang-ruang Kelas, Alih Bahasa Ary Nilandini, Bandung: PT Mizan Media Utama.

Diah Erna Triningsih (2008). Cakap Berbahasa Indonesia, Jakarta: Pusat Perbukuan, Kementerian Pendidikan Nasional.

Depdiknas (2007). Kurikulum Tingkat Satuan Pendidikan Sekolah Dasar. Jakarta : Badan Standar Nasional Pendidikan

E.Kosasih (2008). Apresiasi Sastra Indonesia. Jakarta: Nobel Edumedia.

Heru Kurniawan (2009). Sastra Anak, dalam Kajian Strukturalisme, Sosiologi, Semiotika, hingga Penulisan Kreatif, Yogyakarta: Graha Ilmu

Hudojo. (2002) Peta Konsep, Jakarta: Pusat Perbukuan Depdiknas.

Iwan Sugiarto (2004) Mengoptimalkan Daya Kerja Otak dengan Berpikir Holistik dan Kreatif, Jakarta: Gramedia Pustaka Utama.

Kokonata, (2009). Pengajaran Menulis Puisi di Sekolah Dasar: Jakarta: Bumi Aksara.

Maryanto (2013) Peningkatan Keteram-pilan Menulis Puisi melalui Model Picture And Picture dengan Media Gambar pada Siswa Kelas V SDN Gunungpati 01, (lib.unnes.ac.id/2013) 
Moh. Surya. (1981). Karateristik Pembelajaran, Yogyakarta : Pustaka Belajar

Olivia, Femi. (2008). Gembira Belajar dengan Mind Mapping, Jakarta: Elex Media Komputindo.

Pandley.j.BD.RI.Bretz and J.D. Novak. (1994). Concept maps as tool to assas Learning in Chemmistry. J. of Chemical Education. 71:9-15.

Porter, De Bobbi \& Hernacki, Mike. (2007). Quantum Learning; Membiasakan Belajar Nyaman dan Menyenangkan, Bandung: PT Mizan Publika.

Sulistyono (2008) Dasar, Asas, Fungsi dan Tujuan Pendidikan, Yogyakarta: UNY Press.

Suryabrata, Sumardi. (1984). Interaksi dan Motivasi Belajar. Yogyakarta: Pustaka Bani

Sumiati dan Asra. (2009). Metode Pembelajaran, Bandung: CV. Wacana Prima

Sharifah Maimunah Syed Zin. (2002). Integreted Curiculum for Secondary School (Currriculum Specification Science Form 2). Kuala Lumpur : Pesiaran Duta Off Jalan Duta.

Tarigan, Henry Guntur, (1998). Menulis sebagai Suatu Keterampilan Berbahasa. Bandung: Penerbit Angkasa.

(1982). Prinsip-prinsip Dasar Sastra . Bandung: Angkasa .

The Liang Gie (2002) Terampil Mengarang, Yogyakarta: Andi.

Thobroni, Mustofa. (2008). Belajar dan Pembelajaran: Pengembangan Wacana dan Praktik Pembelajaran dalam Pembangunan Nasional. Jakarta: ArRuzz edia.

Tony Buzan. (2010). Buku Pintar Mind Map untuk Anak, alih bahasa Susi Purwoko, Jakarta : PT Gramedia Pustaka.
Meningkatkan Kreativitas, alih bahasa Eri Suryaputra, Jakarta :PT Gramedia Pustaka Utama.

(2007). Buku Pintar Mind Map, alih bahasa Susi P, Jakarta :PT Gramedia Pustaka Utama.

Tony Buzan dan Barry. (2004.) Memahami Peta Pikiran: The Mind Map Book . Batam: Interaksa

Waluyo, Herman J. (2002). Apresiasi Puisi. Jakarta: Gramedia Pustaka Utama.

Wina Senjaya. (2008). Strategi Pembelajaran. Jakarta: Kencana Prenada Media Group.

Wiwik Listiani. (2013) Efektivitas Metode Mind Mapping dalam Pembelajaran Menulis Puisi pada Siswa Kelas X SMA Negeri 3 Rembang Tahun Ajaran 2013/2014.

(library.ikip pgrismg.ac.id/2013)

Yunus Mohamad (2009) Keterampilan Menulis Dasar. Jakarta: Universitas Terbuka

Yusuf, Wibisono. (2008). Mind Map. Diakses dari (http://ikhs. wordpress.com) tanggal 14 Februari 2012 